EESTI NSV TEADUSTE AKADEEMIA TOIMETISED. XVII KÖDE

KEEMIA * GEOLOOGIA. 1968, Nr. 4

ИЗВЕСТИЯ АКАДЕМИИ НАУК ЭСТОНСКОИ ССР ТОМ ХVII Химия - ГЕология 1968, № 4

\title{
E. MARK-KURIK
}

\section{NEW FINDS OF PSAMMOSTEIDS (HETEROSTRACI) IN THE DEVONIAN OF ESTONIA AND LATVIA}

In recent years a number of psammosteid plates were found in the Middle and Upper Devonian of the Baltic States. These finds complement the material of psammosteids of the Main Devonian Field described by D. Obruchev and E. Mark-Kurik (1965). Among them there are plates unknown yet or known insufficiently. This new material has been used in restorations of various psammosteids (Obruchev, Mark-Kurik, 1968), but it needs a more detailed description.

The present paper contains a description of the new plates and a redescription of those found earlier, belonging to the following species:

Tartuosteus maximus Mark-Kurik

Pycnosteus tuberculatus (Rohon)

Ganosteus stellatus Rohon

Psammolepis toriensis (Mark-Kurik)

P.sl. venyukovi Obruchev

Psammosteus bergi (Obr.)

Ps. livonicus Obr.

Ps. praecursor Obr.

The specimens described are kept in the Geological Museum of the Estonian Academy of Sciences under coll. Nos beginning with "Pi". The diagnoses (with some additions) and the occurrence are by D. Obruchev and E. Mark-Kurik (1965).

\section{E S C R I P T I O N}

FAMILY PSAMMOSTEIDAE TRAQUAIR, 1896

Genus Tartuosteus Obruchev, 1961

Tartuosteus maximus Mark-Kurik, 1965

Figs $1-3$

D i a $\mathrm{g}$ nos is. Species of a very large size. Width of branchial $(57 \mathrm{~cm})$ almost 1.5 times larger than its length. Lateral and hind margins nearly straight, lateral angle comparatively acute. Dorsal plate nearly circular $(1: \mathrm{w}=0.8)$, without tesserae. The flanks of the ventral plate inclined at an angle of $26.5-55^{\circ}$ to the flat, intensively worn bottom. The posterior notch, 
extending nearly to the centre of growth, is completely closed up in later representatives. Tubercles small or middle-sized $(0.3-0.4 \mathrm{~mm})$, square or hexagonal, lozenge or fan-shaped, elongated, irregular, with rather short and dense crenulation.

Occurrence. Middle Devonian (Givetian) Burtnieki beds of Estonia. Localities: Karksi, Härma and probably Tarvastu.

$M$ a t e r i a l: dorsal, postorbital, cornual, branchial and ventral plates. New finds: a fragment of dorsal plate with sensory canals, postorbital and nearly complete ventral.

\section{Description.}

Dorsal plate. A fragment of dorsal plate of an adult individual and two plates of young ones have been previously described (Obruchev and MarkKurik, 1965; Figs 59-61). Specimen Pi 906 (Fig. 1) is a fragment of the central part of a comparatively young individual. Its length is

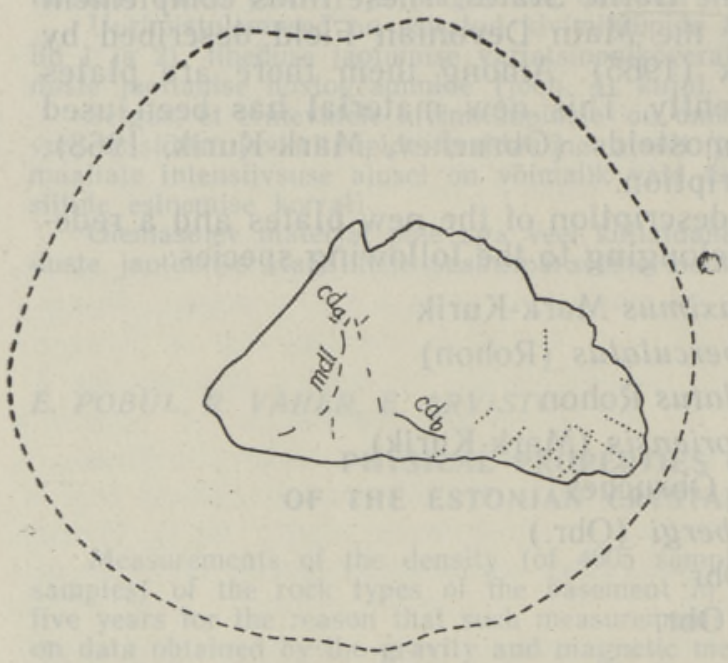
9.7 , width $17.7 \mathrm{~cm}$. The nearly circular outline has been restored on the basis of growth lines. and other specimens. On the outer surface, the tubercles have been removed and the sensory grooves opened. There are two medial dorsal lines (mdl) which come nearer to one another in front at the growth centre,

Fig. 1. Tartuosteus maximus, dorsal plate of a young individual, $\mathrm{Pi} 906$, $\times 1 / 4 \cdot \mathrm{cd}_{\mathrm{a}-\mathrm{b}}$ - transverse commissures, mdl - medial dorsal canal. Karksi, Burtnieki beds.

one short branch of transverse commissure $\left(\mathrm{cd}_{\mathrm{a}}\right)$ directed forward and two commissures $\left(\mathrm{cd}_{\mathrm{b}}\right)$ going backwards.

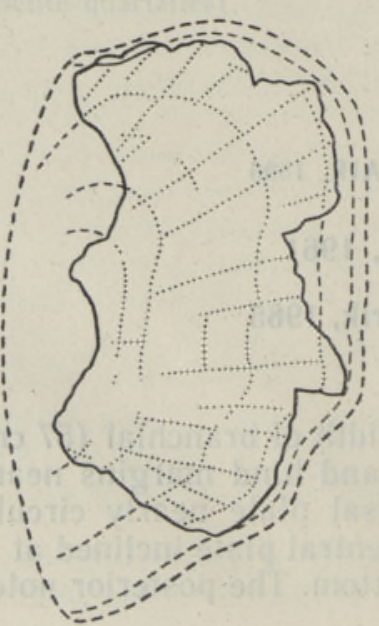

Postorbital plate (Pi 187, Fig. 2) has almost entirely broken-off edges. Its incomplete length is $10 \mathrm{~cm}$, width $5.5 \mathrm{~cm}$. The plate is flat and thin (1-2.4 $\mathrm{mm})$, and bearing well marked growth and radial lines allowing to restore the outline of the plate and to locate the position of growth centre approximately at the middle of the lateral edge. The unornamented margins were probably very narrow (about $3 \mathrm{~mm}$ ).

Ventral plate. The specimens described by D. Obruchev and E. Mark-Kurik, 1965 (Figs 6366) were only fragments. Now we possess an almost complete plate from Karksi (Pi 915, Fig. 3). The unornamented margins are some-

Fig. 2. Tartuosteus maximus, left postorbital plate, Pi $187, \times^{1 / 2}$. Karksi, Burtnieki beds. 

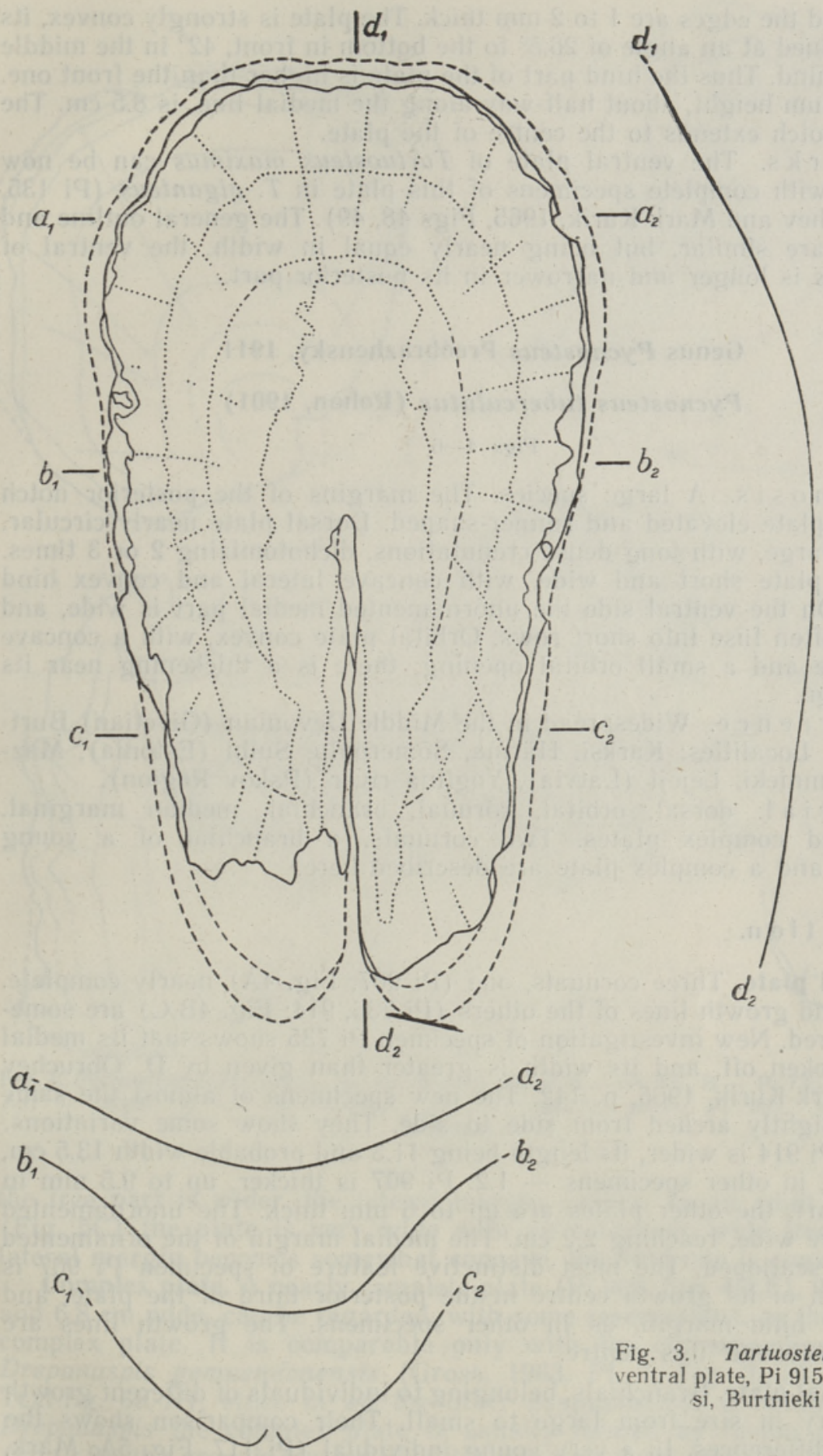

Fig. 3. Tartuosteus maximus, ventral plate, $\mathrm{Pi} 915, \times^{1 / 4}$. Karksi, Burtnieki beds.

what broken. The plate is $48 \mathrm{~cm}$ long and $25 \mathrm{~cm}$ wide. When complete, it must have been about $2-3 \mathrm{~cm}$ longer and wider. The ratio of maximum length to maximum width $(1: \mathrm{w})$ is 1.9 . The central heavily abraded portion 
is $5 \mathrm{~mm}$ and the edges are 1 to $2 \mathrm{~mm}$ thick. The plate is strongly convex, its flanks inclined at an angle of $26.5^{\circ}$ to the bottom in front, $42^{\circ}$ in the middle and $55^{\circ}$ behind. Thus the hind part of the plate is higher than the front one. The maximum height, about half-way along the medial line, is $8.5 \mathrm{~cm}$. The posterior notch extends to the centre of the plate.

$\mathrm{Re}$ marks. The ventral plate of Tartuosteus maximus can be now compared with complete specimens of this plate in $T$. giganteus ( $\mathrm{Pi} 135$, 136; Obruchev and Mark-Kurik, 1965, Figs 48, 49). The general outline and convexity are similar, but being nearly equal in width, the ventral of T. maximus is longer and narrower in its posterior part.

\title{
Genus Pycnosteus Preobrazhensky, 1911
}

\section{Pycnosteus tuberculatus (Rohon, 1901)}

\author{
Figs $4-6$
}

Di a g nosis. A large species. The margins of the posterior notch of ventral plate elevated and runner-shaped. Dorsal plate nearly circular. Tubercles large, with long densé crenulations, dichotomizing 2 or 3 times. Branchial plate short and wide, with concave lateral and convex hind margins. On the ventral side the unornamented medial part is wide, and tubercles often fuse into short rows. Orbital plate convex, with a concave lateral side and a small orbital opening; there is a thickening near its lateral edge.

Oc currence. Widespread in the Middle Devonian (Givetian) Burtnieki beds. Localities: Karksi, Härma, Sõmerpalu, Sulbi (Estonia), Mazsalaca, Ramnieki, Lējēji (Latvia), Yoglina river (Pskov Region).

M at eria 1: dorsal, orbital, cornual, branchial, median marginal, ventral and complex plates. Two cornuals, a branchial of a young individual and a complex plate are described here.

\section{Description.}

Cornual plate. Three cornuals, one (Pi 907, Fig. 4A) nearly complete. Margins and growth lines of the others (Pi 735, 914; Fig. 4B,C) are somewhat restored. New investigation of specimen Pi 735 shows that its medial edge is broken off, and its width is greater than given by D. Obruchev and E. Mark-Kurik, 1965, p. 142. The new specimens of almost the same size are slightly arched from side to side. They show some variations: specimen $\mathrm{Pi} 914$ is wider, its length being 11.3 and probable width $13.5 \mathrm{~cm}$, $1: \mathrm{w}=0.8$, in other specimens -1.2 . Pi 907 is thicker, up to $9.5 \mathrm{~mm}$ in its hind part, the other plates are up to $6 \mathrm{~mm}$ thick. The unornamented margins are wide, reaching $2.2 \mathrm{~cm}$. The medial margin of the ornamented surface is scalloped. The most distinctive feature of specimen $\mathrm{Pi} 907$ is the position of its growth centre in the posterior third of the plate, and not at the hind margin, as in other specimens. The growth lines are concentric around this centre.

Branchial plate. Branchials, belonging to individuals of different growth stages, vary in size from large to small. Their comparison shows the following differences. In a very young individual (Pi 117, Fig. 5A; Mark, 1956, Pl. I, Fig. 3) the branchial has a very narrow free lateral part; the lateral margin is convex, the hind one slightly concave or convex (in $\mathrm{Pi}$ 741; Obruchev and Mark-Kurik, 1965, Fig. 89). In the fragment of a somewhat older individual (Pi 908, Fig. 5B), $11.5 \mathrm{~cm}$ long and $12.5 \mathrm{~cm}$ wide, 

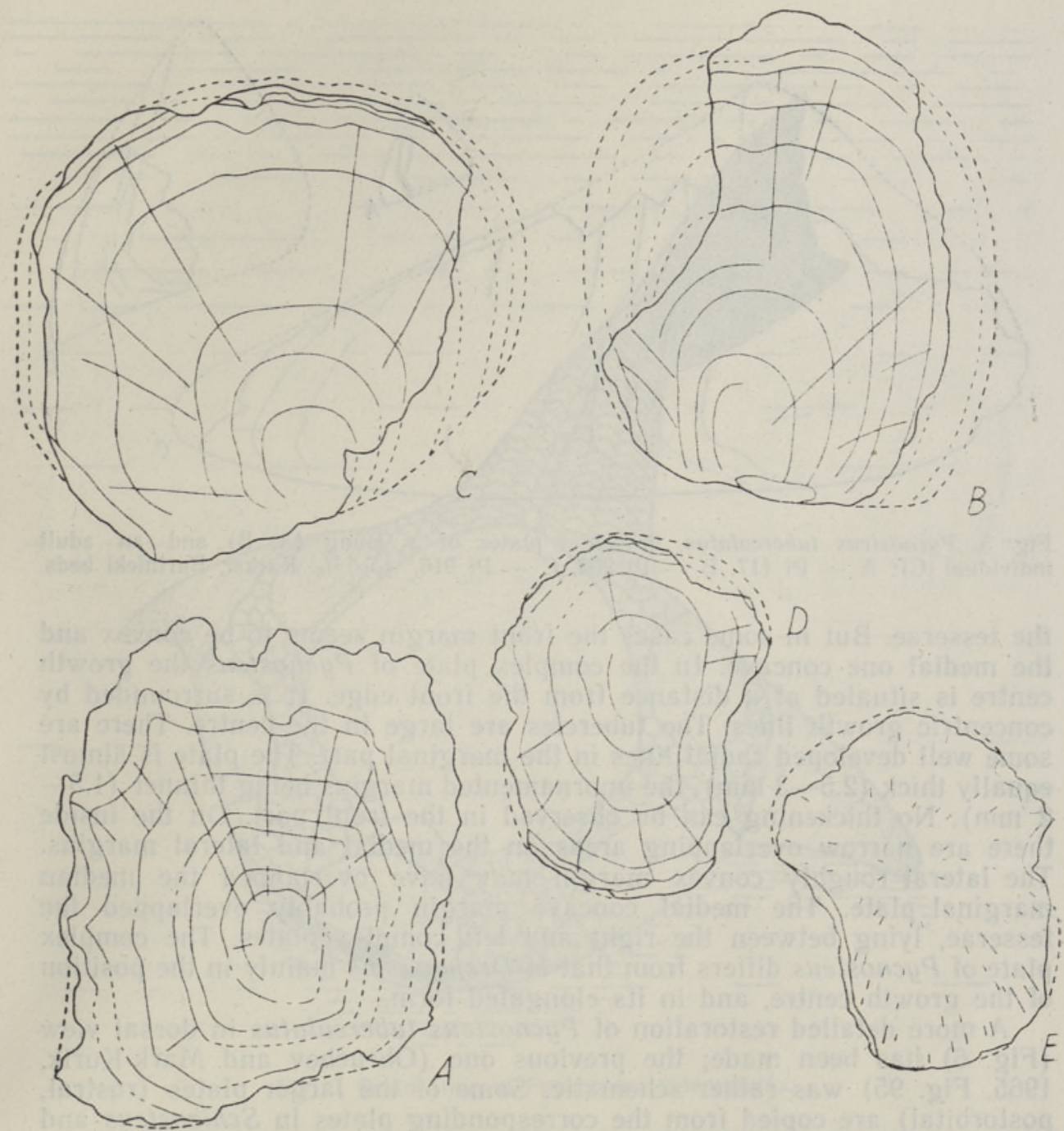

Fig. 4. Pycnosteus tuberculatus. A-C: cornual plates, A - Pi 907, B - Pi 735, C - Pi 914; A,C - right, B - left cornual. D,E - complex plate, Pi 909, $\times^{1 / 2}$. Karksi, Burtnieki beds.

the free part is wider, the lateral margin convex. In an adult individual (Fig. 5C) the plate is very wide with an extremely wide free part, the lateral margin becomes somewhat concave, the hind one is convex.

Complex plate. A nearly complete plate (Pi 909, Fig. 4D,E), $9.1 \mathrm{~cm}$ long and $6.8 \mathrm{~cm}$ wide, can be regarded, with some reservations, as the right (?) complex plate. It is comparable only with the corresponding plate of Drepanaspis gemuendenensis (Gross, 1963, Pl. 7, Fig. 3; Pl. 9, Fig. 2; Text-fig. $6 \mathrm{~K}-\mathrm{N})$, since in all the other psammosteids it is unknown. In Drepanaspis the complex plate is usually formed by fusion of tesserae (up to 9), the growth centres of which, bearing large tubercles, are visible. But there are some specimens with only one growth centre near the middle of the thickened front edge, around which the tubercles and growth lines are arranged concentrically. The shape of the margins of the complex plates in Drepanaspis is variable, depending on the number and outline of 


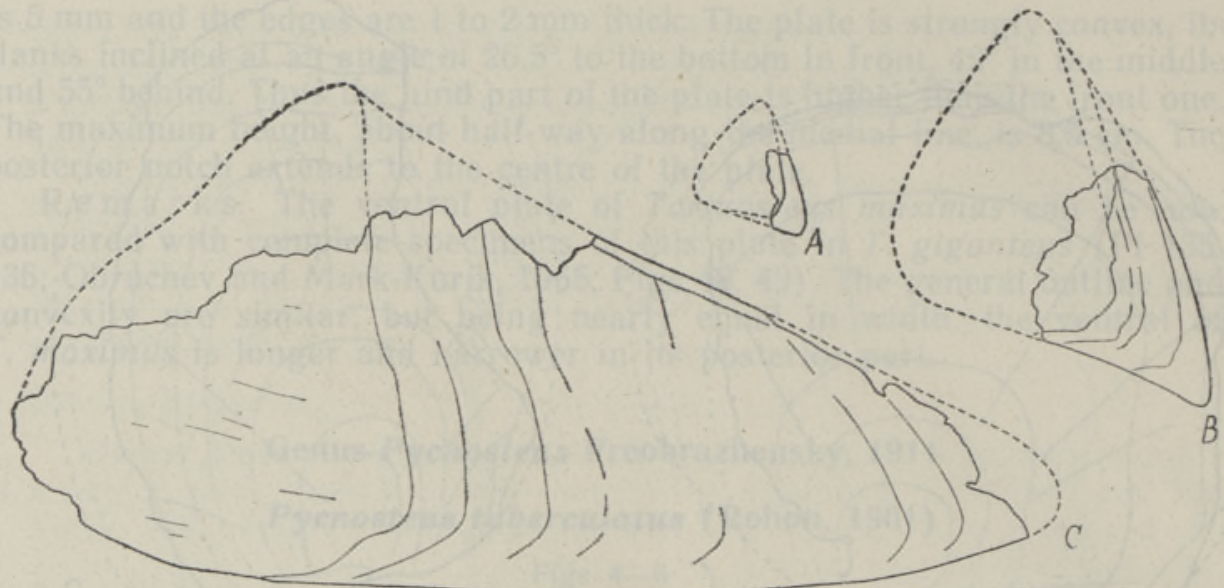

Fig. 5. Pycnosteus tuberculatus, branchial plates of a young (A, B) and an adult individual $(\mathrm{C}) ; \mathrm{A}-\mathrm{Pi} 117, \mathrm{~B}-\mathrm{Pi} 908, \mathrm{C}-\mathrm{Pi} 916, \sim \times 1 \%$. Karksi, Burtnieki beds.

the tesserae. But in some cases the front margin seems to be convex and the medial one concave. In the complex plate of Pycnosteus the growth centre is situated at a distance from the front edge. It is surrounded by concentric growth lines. The tubercles are large in the centre. There are some well developed radial lines in the marginal part. The plate is almost equally thick $(2.5-3 \mathrm{~mm})$, the unornamented margins being thinner $(1.5-$ $2 \mathrm{~mm}$ ). No thickening can be observed in the front part. On the inside there are narrow overlapping areas on the medial and lateral margins. The lateral roughly convex margin may have overlapped the median marginal plate. The medial concave margin probably overlapped the tesserae, lying between the right and left complex plates. The complex plate of Pycnosteus differs from that of Drepanaspis mainly in the position of the growth centre, and in its elongated form.

A more detailed restoration of Pycnosteus tuberculatus in dorsal view (Fig. 6) has been made; the previous one (Obruchev and Mark-Kurik, 1965, Fig. 95) was rather schematic. Some of the larger plates (rostral, postorbital) are copied from the corresponding plates in Schizosteus and Tartuosteus, the mouth and tail are depicted as in Drepanaspis (Gross, 1963, Figs 10,11A). A restoration of $P$. tuberculatus was given by B. J. and L. B. Tarlo (1965, Fig. 1), but because of these authors' insufficient acquaintance with the structure of Pycnosteus and related forms, the outlines of some plates and the course of their growth lines (especially in cornuals and postorbitals) are in their restoration very far from reality.

\section{Genus Ganosteus Rohon, 1901}

\section{Ganosteus stellatus Rohon, 1901}

Fig. 7

D i a g n os is. A large species. Branchial plate wide, with long base. Dorsal plate heart-shaped, the centre of growth almost in centre of the plate, $1: \mathrm{w}=0.9$. The posterior notch of the oval ventral plate covered by tesserae extends nearly to the growth centre or is entirely closed up.

O c currence. Appears probably in the uppermost Aruküla beds (Middle Devonian, Givetian) Estonia. Widespread in Burtnieki beds, 


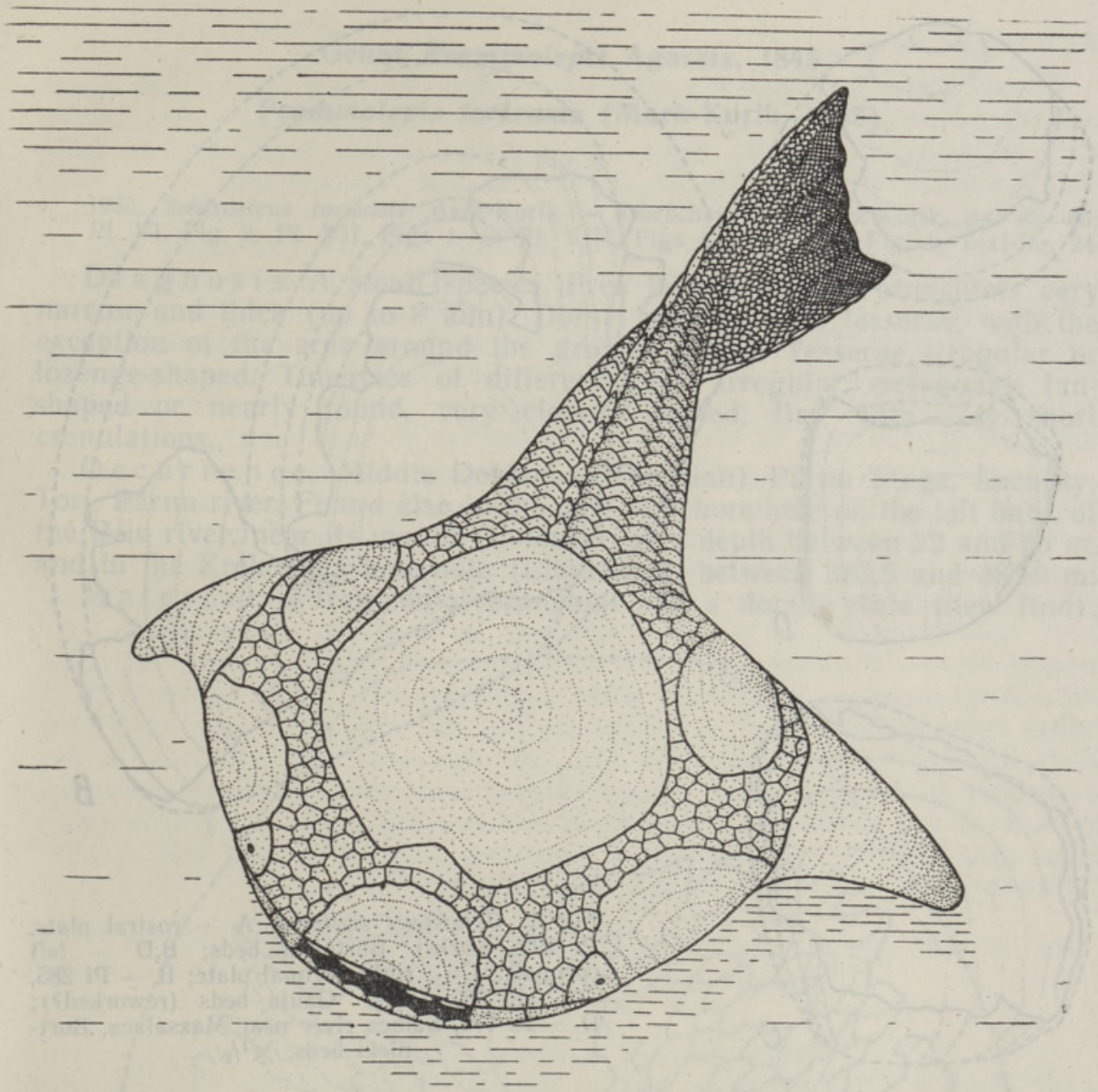

Fig. 6. Restoration of Pycnosteus tuberculatus.

Estonia (Karksi, Sōmerpalu, Sulbi), Latvia (Salaca river, Ramnieki, Burtnieki), Pskov Region (Yoglina river). Rare in the Upper Devonian (Frasnian) Gauja beds and at the base of the Amata beds of Leningrad Region (reworked).

$M$ a t e ri a l: rostral, dorsal, cornual, branchial, and ventral plates (the rostral is a new find). Three cornuals are redescribed.

Description.

Rostral plate ( $\mathrm{Pi} 292$, Fig. 7A) is fragmental; length and width are $5.5 \mathrm{~cm}$. The plate was probably oval with nearly straight lateral margins. It is thicker $(4 \mathrm{~mm})$ near the growth centre in the middle of the front margin. On the inside this margin is covered by tubercles which form a brim, up to $6 \mathrm{~mm}$ wide.

Cornual plate. Three cornuals of different size and shape have been found. Specimen Pi 285 (Fig. 7B) is the largest known psammosteid cornual. It is broken in front and behind, but judging by the growth lines it was nearly oval in outline. The fragment is $9.8 \mathrm{~cm}$ long, and $17.4 \mathrm{~cm}$ wide. 


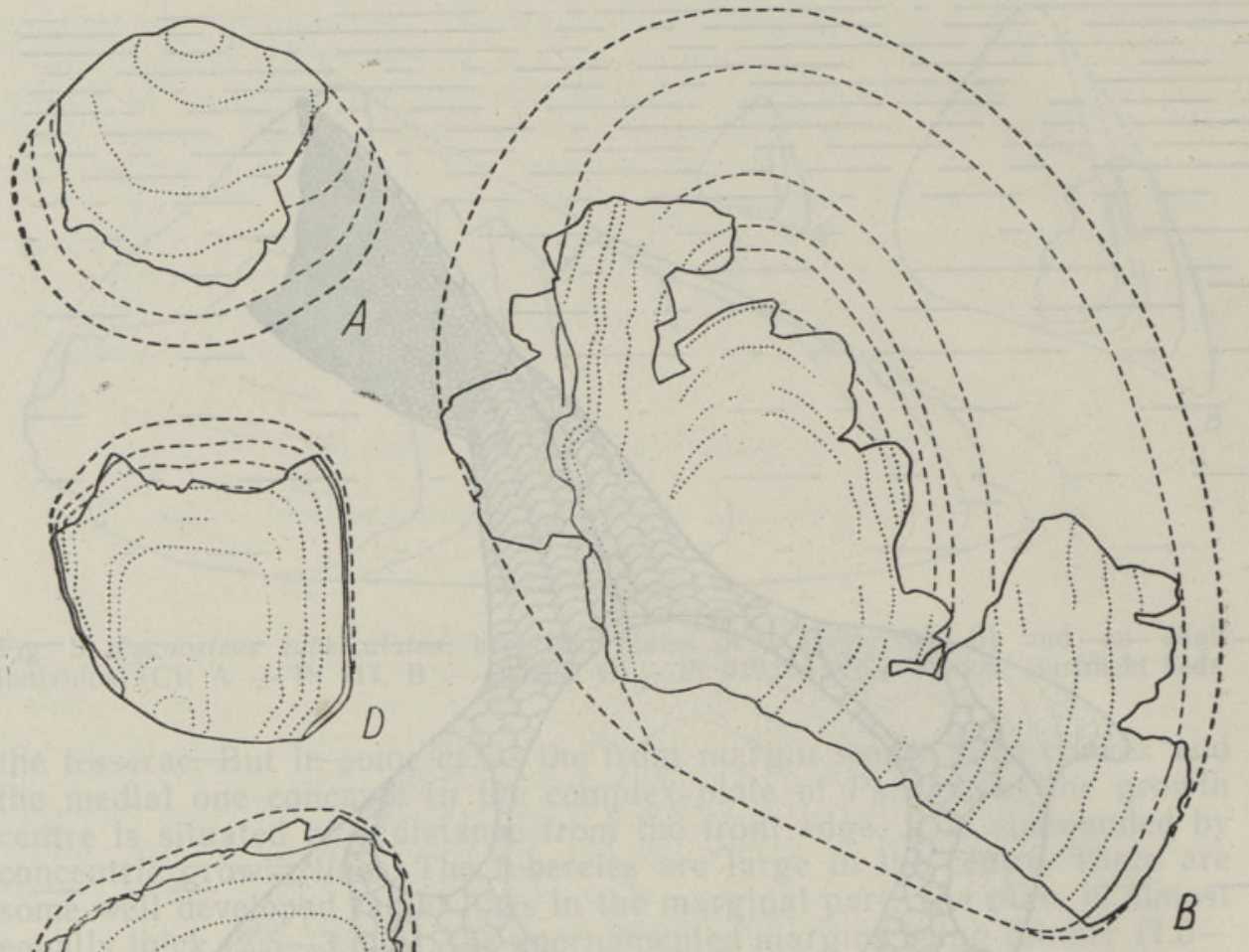

Fig. 7. Ganosteus stellatus, A - rostral plate, $\mathrm{Pi}^{2}$ 292, Karksi, Burtnieki beds; B,D - leit cornuals, C - right cornual plate; B - Pi $285_{r}$ C - Pi 282, Lëjej, Gauja beds (reworked?); D - Pi 174, Salaca river near Mazsalaca, Burtnieki beds. $X^{1 / 2}$.

When complete, the length of the plate might have been $16 \mathrm{~cm}$, the width more than $15 \mathrm{~cm}$. It is rather thick: $6-8 \mathrm{~mm}$ near the growth centre. The lateral unornamented margin is very wide (up to $2.9 \mathrm{~cm}$ ). This margin was covered by tesserae, lying between the cornual and the branchial. A lot of irregular secondary tubercles with blunt smooth tops cover the centre of the plate.

The other specimens ( $\mathrm{Pi} 282$, 174; Fig. 7C,D) belong to younger individuals. They are more quadrangular in shape and their unornamented margins are narrower. $\mathrm{Pi} 282$ with broken hind part is $6.8 \mathrm{~cm}$ long and $7.5 \mathrm{~cm}$ wide. The outline and growth lines of the smallest plate ( $\mathrm{Pi} 174)$ are restored anew. The medial margin of this plate is not a complete one, as it was supposed previously (Obruchev and Mark-Kurik, 1965, Fig. 113). The description and schematic drawings of the three mentioned cornuals have been given by L. B. Tarlo (1965, Fig. 21F-H) too, but the position of these plates has been confused by him. In reality the specimens Pi 285 and 174 are from left side, and Pi 282, from the right. 
Genus Psammolepis Agassiz, 1845

\section{Psammolepis toriensis (Mark-Kurik, 1965)}

Fig. 8

1965. Schizosteus toriensis Mark-Kurik - Obruchev and Mark-Kurik, pp. 85-86; Pl. VI, Fig. 9; Pl. VII, Figs 1-3; Pl. VIII, Figs 1-3; Pl. IX, Fig. 1; Text-fig. 24

Di a g nos is. A small species. Free lateral part of branchials very narrow and thick (up to $9 \mathrm{~mm}$ ). Dorsal covered with tesserae, with the exception of the area around the growth centre. Tesserae irregular or lozenge-shaped. Tubercles of different sizes, irregular, polygonal, fanshaped or nearly round, very closely packed, flat, with very short crenulations.

Occurrence. Middle Devonian (Givetian) Pärnu Stage. Locality: Tori, Pärnu river. Found also in the core of a bore-hole on the left bank of the Reiu river, near its mouth (Estonia), at a depth between 22 and $23 \mathrm{~m}$, and in the Krekenava bore-hole (Lithuania), between 383.5 and $383.6 \mathrm{~m}$.

$\mathrm{M}$ ateri a l: a fragmental branchial and a dorsal plate (new find).

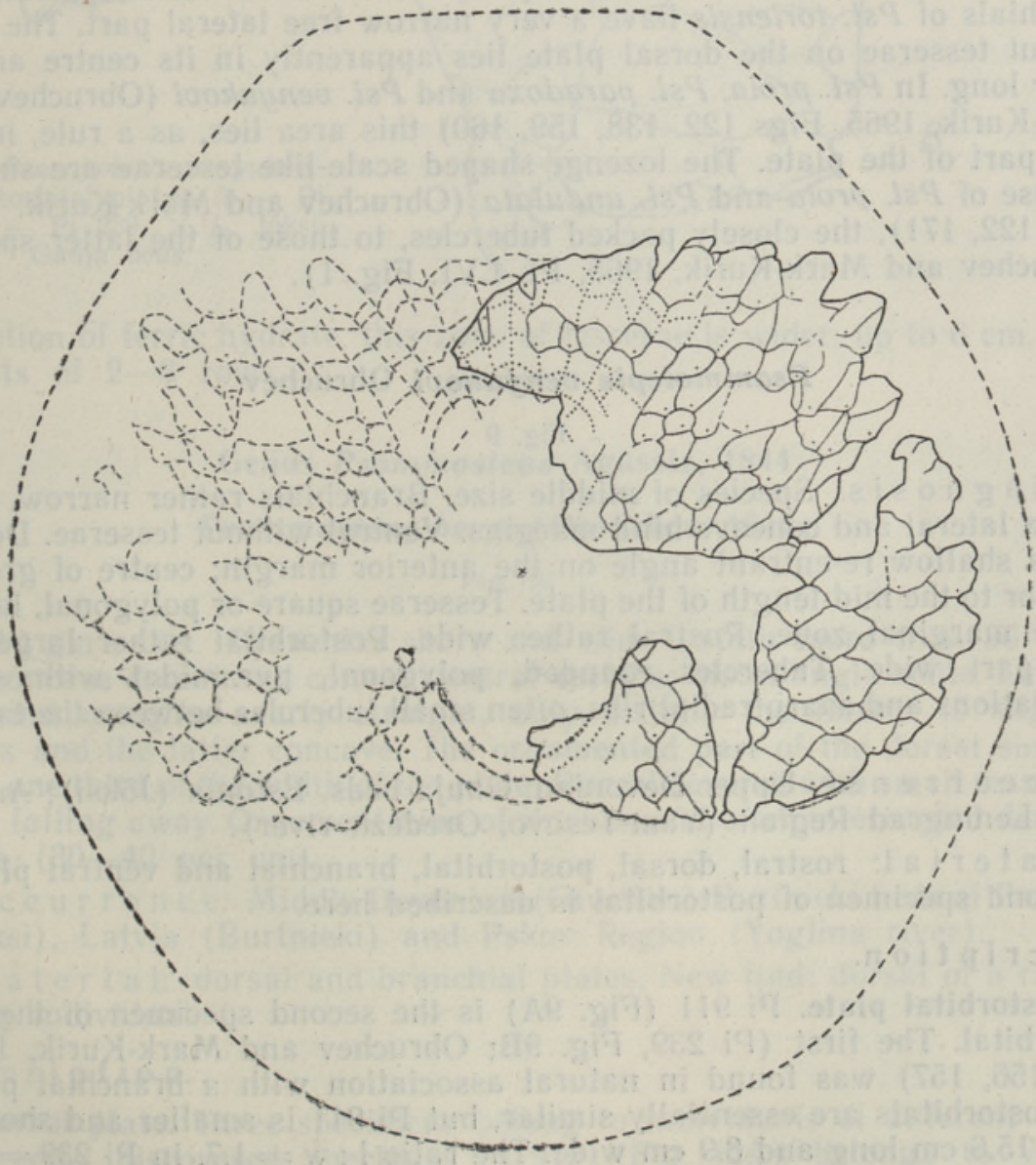

Fig. 8. Psammolepis toriensis, dorsal plate, Pi $910, X^{1 / 2}$. Bore hole on left bank of Reiu river, near its mouth, Pärnu Stage 


\section{Description.}

Dorsal plate. A fragment with tesserae, described previously (Obruchev and Mark-Kurik, 1965; p. 86; Pl. IX, Fig. 1) belongs evidently to the dorsal plate. A larger piece of the right side of this plate has been found in Reiu river bore-hole ( $\mathrm{Pi} \mathrm{910;} \mathrm{Fig.} \mathrm{8).} \mathrm{Its} \mathrm{measurements} \mathrm{correspond} \mathrm{to} \mathrm{the} \mathrm{dia-}$ meter of the core $(12.5 \mathrm{~cm})$. The width of the plate was probably not less than $20 \mathrm{~cm}$, the length somewhat greater, about $24 \mathrm{~cm}$. The major part of the fragment is covered with irregular or lozenge-shaped tesserae, whose growth centres are at their hind tips. Tesserae are $0.6-1.5 \mathrm{~cm}$ long and $0.6-1.8 \mathrm{~cm}$ wide. The growth lines on the left side of the fragment show that in the centre of the plate an oval area devoid of tesserae was present. In front of this area, the plate was not entirely covered with tesserae. The tubercles of specimen $\mathrm{Pi} 910$ are characteristic of the species.

Remarks. This species was previously referred to the genus Schizosteus because of its narrow and long branchial plate with a very narrow free lateral part. But, its dorsal plate being covered by tesserae, it should belong to Psammolepis. Psl. toriensis is of great interest as the earliest, Givetian member of this genus. Most of Psammolepis species come from the lower Frasnian. As compared with these later species, the branchials of $P s l$. toriensis have a very narrow free lateral part. The area without tesserae on the dorsal plate lies apparently in its centre and is rather long. In Psl. proia, Psl. paradoxa and Psl. venyukovi (Obruchev and Mark-Kurik, 1965, Figs 122, 138, 159, 160) this area lies, as a rule, in the front part of the plate. The lozenge-shaped scale-like tesserae are similar to those of Psl. proia and Psl. undulata (Obruchev and Mark-Kurik, 1965, Figs 122, 171), the closely packed tubercles, to those of the latter species (Obruchev and Mark-Kurik, 1965, Pl. LVI, Fig. 1).

\section{Psammolepis venyukovi Obruchev}

Fig. 9

Di a g n o sis. Species of middle size. Branchials rather narrow, with convex lateral and concave hind margins. Ventral without tesserae. Dorsal with a shallow re-entrant angle on the anterior margin; centre of growth anterior to the mid-length of the plate. Tesserae square or polygonal, larger in the marginal zone. Rostral rather wide. Postorbital rather large, its hind part wide. Tubercles rounded, polygonal, pyramidal with short crenulations and sharp radial ribs, often small tubercles between the larger ones.

O c c urre n c e. Upper Devonian, Gauja beds, Estonia (Jõksi); Amata beds, Leningrad Region (Yam-Tesovo, Oredezh river).

M a teri a l: rostral, dorsal, postorbital, branchial and ventral plates. A second specimen of postorbital is described here.

\section{Description.}

Postorbital plate. Pi 911 (Fig. 9A) is the second specimen of the left postorbital. The first ( $\mathrm{Pi} 239$, Fig. 9B; Obruchev and Mark-Kurik, 1965, Figs 156,157 ) was found in natural association with a branchial plate. The postorbitals are essentially similar, but $\mathrm{Pi} 911$ is smaller and shorter, being $15.6 \mathrm{~cm}$ long and $8.9 \mathrm{~cm}$ wide. The ratio $1: \mathrm{w}=1.7$, in $\mathrm{Pi} 239=2.1$. The medial margin of $\mathrm{Pi} 911$ bears a zone of large tesserae, $2-3 \mathrm{~cm}$ in width. In $\mathrm{Pi} 239$, the medial margin of which is partly covered with a 


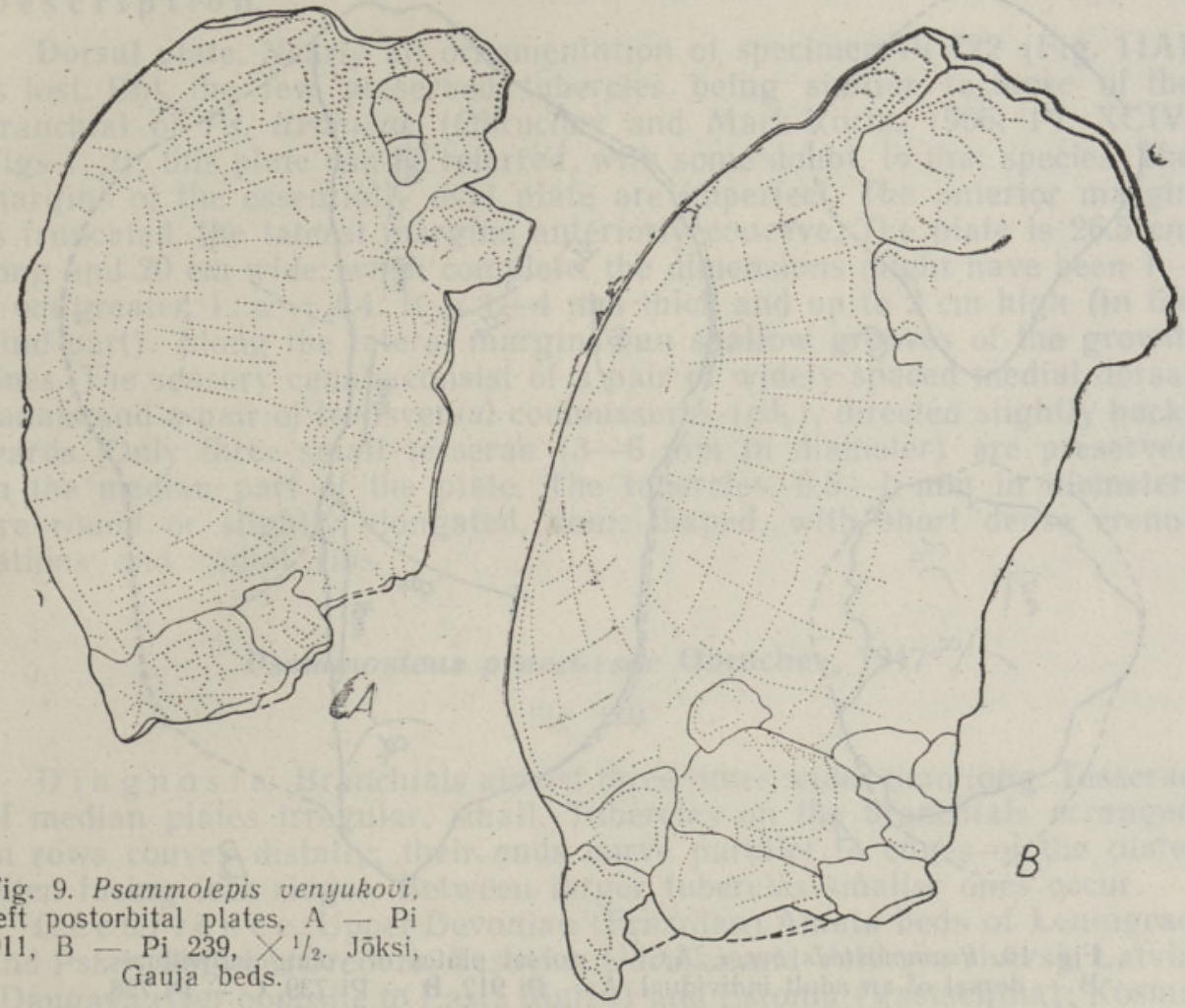

concretion of ferric hydrate, this zone of tesserae is wider, up to $6 \mathrm{~cm}$, and consists of $2-3$ rows.

Genus Psammosteus Agassiz, 1844

\section{Psammosteus bergi (Obruchev, 1943)}

Fig. 10

D i a g nos is. Branchial short and wide (width more than $36 \mathrm{~cm}$ ), with concave dorsal and convex ventral surface; distal angle acute. Lateral and hind margins nearly straight, only distally the former is slightly convex and the latter concave. The ornamented part of the dorsal surface forms one third of the width of the plate. Dorsal covered with small tesserae, easily falling away. Ornamentation of sinuous and often interrupted dentine ridges $(30-40$ per $\mathrm{cm})$.

O c c ur r e n ce. Middle Devonian (Givetian) Burtnieki beds of Estonia (Karksi), Latvia (Burtnieki) and Pskov Region (Yoglina river).

$\mathrm{M}$ a te $\mathrm{r}$ i a l: dorsal and branchial plates. New find: dorsal of a rather young individual.

Description.

Dorsal plate. Three specimens belong to individuals of different ages. A recently discovered specimen Pi 912 (Fig. 10A) belongs to young individual. It is $14 \mathrm{~cm}$ long and $12.2 \mathrm{~cm}$ wide. When complete, it might have been $17 \mathrm{~cm}$ long and $13.5 \mathrm{~cm}$ wide. Thus this plate is only half as 

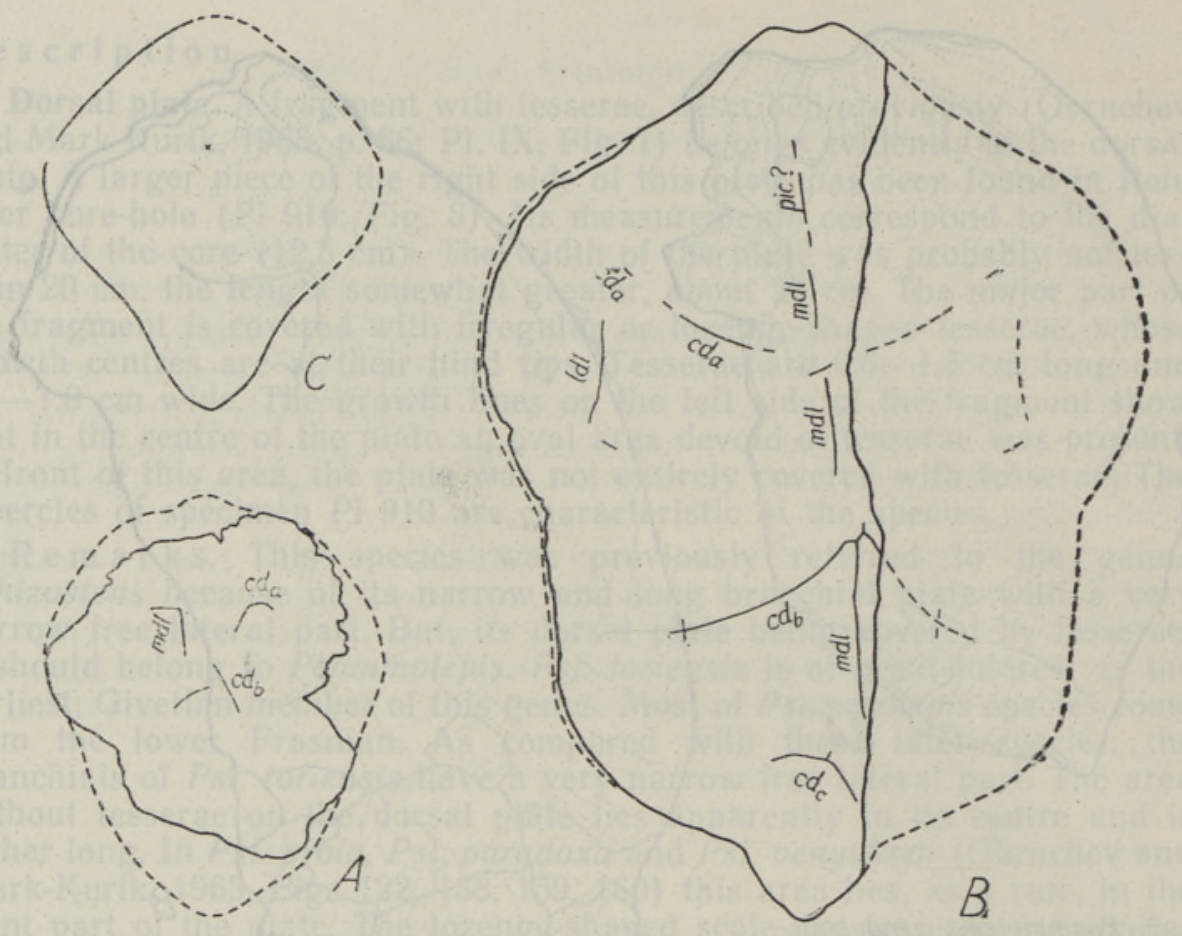

Fig. 10. Psammosteus bergi, A,C - dorsal plates of young individuals, $\mathrm{B}-$ dorsal of an adult individual. A $-\mathrm{Pi} 912$, B $-\mathrm{Pi} 739, \mathrm{C}-\mathrm{Pi} 728$, $\times 1 / 4 \cdot \mathrm{cd}_{\mathrm{a}-\mathrm{c}}$ - transverse commissures, $\mathrm{ldl}$ - lateral dorsal canal, mdl medial dorsal canal, pic - pineal canal. Karksi, Burtnieki beds.

large as that of an adult individual ( $\mathrm{Pi} 739$, Fig. 10B; Obruchev and Mark-Kurik, 1965, Figs 185, 186) and hardly larger than Pi 728, Fig. 10C; Obruchev and Mark-Kurik, 1965, Fig. 189. The small tesserae of Pi 912 are lost, and the sensory canals visible. Their pattern is not completely developed, and consists of short medial dorsal canals (mdl) and two transverse commissures $\left(\mathrm{cd}_{\mathrm{a}}, \mathrm{cd}_{\mathrm{b}}\right)$, which are shorter and more widely spaced than the corresponding canals of an adult individual.

\section{Psammosteus livonicus Obruchev, 1965}

Fig. $11 \mathrm{~A}$

D i a g nosis. Branchial thin, with a rather long base, tubercles on the ventral surface cover more than half the width of the plate. Dorsal probably in general oval, with truncated anterior margin, its lateral margins concave anteriorly. Tubercles large, high, with sharp radial ribs, sometimes reaching the top. Crenulations seldom branching, with truncated ends. Transversal rows of tubercles unclear. Smaller tubercles between the large ones.

Occurrence. Upper Devonian (Frasnian) Amata beds. Only type locality on the left bank of Daugava opposite Pasta Muiža (Latvia).

$M$ a terial: branchial and dorsal plates. 


\section{Description.}

Dorsal plate. Nearly all ornamentation of specimen Pi 722 (Fig. 11A) is lost. But, the few preserved tubercles being similar to those of the branchial of Ps. livonicus (Obruchev and Mark-Kurik, 1965; Pl. XCIV, Figs 1,2$)$, this plate can be referred, with some doubt, to that species. The margins of the essentially oval plate are imperfect. The anterior margin is truncated, the lateral margins anteriorly concave. The plate is $26.5 \mathrm{~cm}$ long and $20 \mathrm{~cm}$ wide; when complete, the dimensions might have been 1 -$2 \mathrm{~cm}$ greater, $1: \mathrm{w}=1.4$. It is $1-4 \mathrm{~mm}$ thick and up to $2 \mathrm{~cm}$ high (in the hind part). Along the lateral margins run shallow grooves of the growth lines. The sensory canals consist of a pair of widely spaced medial dorsal canals and a pair of transversal commissures $\left(\mathrm{cd}_{\mathrm{b}}\right)$, directed slightly backwards. Only three small tesserae $(3-6 \mathrm{~mm}$ in diameter) are preserved in the median part of the plate. The tubercles, $0.5-1 \mathrm{~mm}$ in diameter, are round or slightly elongated, dome-shaped, with short dense crenulations and radial ribs.

\section{Psammosteus praecursor Obruchev, 1947}

Fig. 11B

D i a g n o s is. Branchials almost three times wider than long. Tesserae of median plates irregular, small. Tubercles on the branchials arranged in rows convex distally; their ends curve parallel to edges of the plate, often fusing into ridges. Between larger tubercles smaller ones occur.

O c c u r re n c e. Upper Devonian (Frasnian) Amata beds of Leningrad and Pskov Region (Oredezh, Tesovka, Udraika and Velikaya rivers), Latvia (Daugava river opposite to Pasta Muiža) and Estonia (Vastseliina); Kosma beds of Timan [Tsilma river and Vyuchei bore-hole (?)].

$\mathrm{M}$ a te ri a l: branchial, ventral (?) and dorsal (?) plates.

Description.

Dorsal plate. The history of the supposed dorsal plates is rather complicated. Two specimens have been found in Vastseliina (Estonia). One of them, Pi 150, was described by I. Preobrazhensky (1911, p. 34; Pl. V, Fig. 12) as probably belonging to Dyptychosteus tesselatus Preobr. But as all features of this plate are typical of Psammosteus, there was no need for a special generic name, and the plate was assigned to Psammosteus (Mark, 1955 , pp. 4, 6). L. B. Tarlo (1961) provided the species with a new name, Psammosteus markae, since $P$ s. tessellatus was preoccupied by R. H. Traquair (1897) for a species from Scotland, lately referred by Tarlo (1965) to Psammolepis undulata. But, as Ps. markae was proposed as a substitute name of Ps. tesselatus, and this latter is synonymous with Ps. megalopteryx Trautschold, the plate $\mathrm{Pi} 150$ remains without a name. It is likely that it belongs to some species of Psammosteus known from the Amata beds.

The specimen Pi 150, an incomplete plate, as well as Pi 164, an almost entirely preserved specimen, are partly covered with poorly preserved tubercles, similar to those of the branchials of Ps. praecursor (Obruchev and Mark-Kurik, 1965, Pl. LXVII, Figs 3, 5). Pi 164 [Fig. 11B; in Tarlo's Fig. 42, Tarlo (1965) figured upside down] is oval in outline. Its incomplete length is $29.6 \mathrm{~cm}$, width $22 \mathrm{~cm}, 1: \mathrm{w}=1.4$. It is $1-4 \mathrm{~mm}$ thick. The plate is arched in its hind part (up to $2 \mathrm{~cm}$ ) and has a median longitudinal groove, extending towards a short process in the middle of the hind margin. 


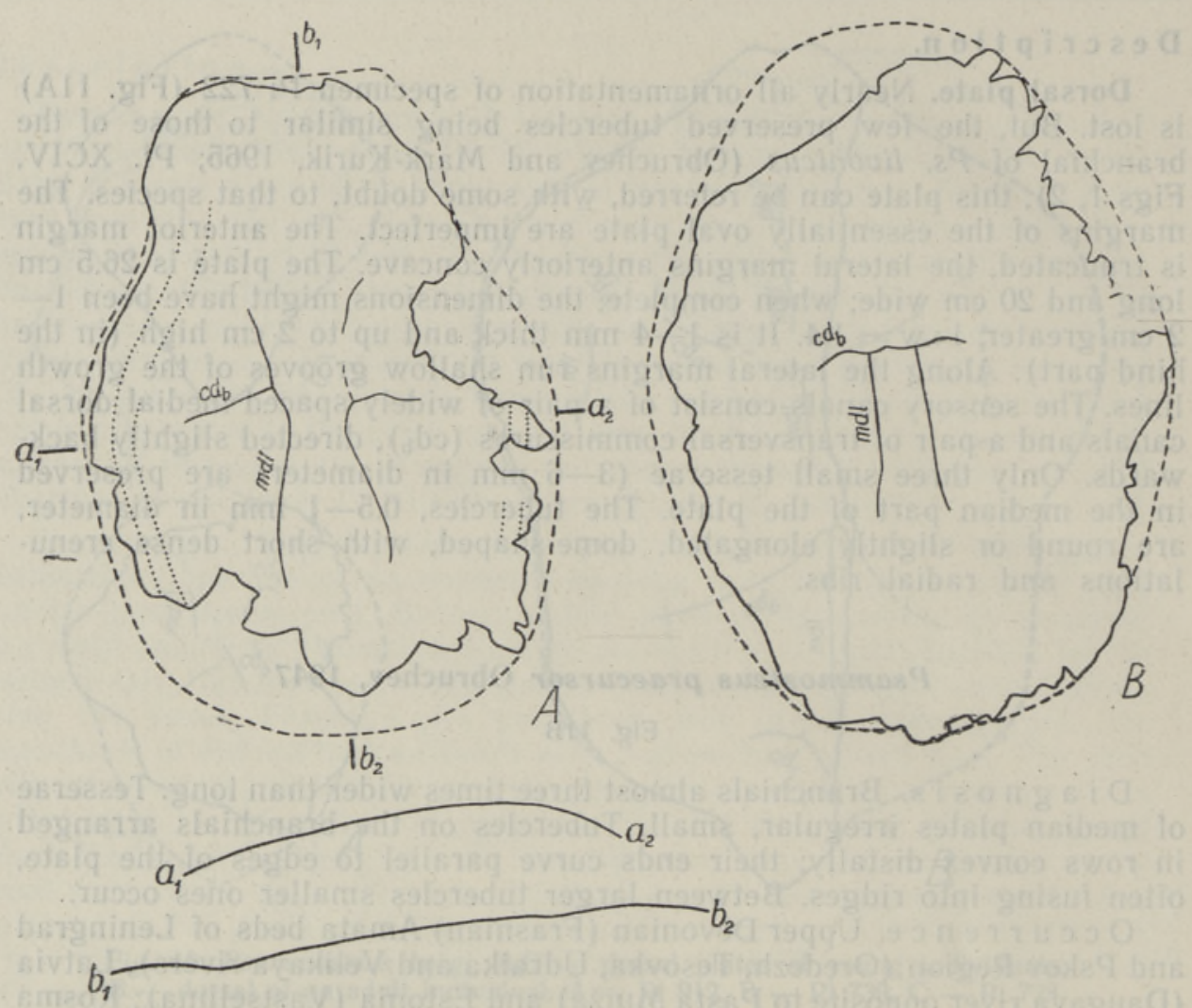

Fig. 11. Dorsal plates: A - Psammosteus livonicus, Pi 722, Daugava river opposite Pasta Muiža, Amata beds; B - Ps. praecursor, Pi 164, Vastseliina, Amata beds. $X 1 / 4 \cdot \mathrm{cd}_{\mathbf{b}}$ - transverse commissure, mdl - medial dorsal canal.

The lateral margins are convex and evidently straight or slightly convex anteriorly. The sensory canal system consists of a pair of medial dorsal canals diverging somewhat posteriorly, and a transverse commissure $\left(\mathrm{cd}_{\mathrm{b}}\right)$. The tesserae are round or polygonal, $3-4 \mathrm{~mm}$ in diameter. Small tubercles $(22-24$ per $\mathrm{cm})$ are round or elongated, with rather long crenulations and ribs reaching the tops. They are arranged in concentric rows around larger tubercles.

$\mathrm{Re} \mathrm{m}$ a rks. The dorsal plate shows a number of similarities to that of Ps. livonicus. Both plates are nearly equal in size, $1: \mathrm{w}$ is the same (1.4), they are shaped and arched similarly. The dimensions of tesserae are also similar. However, the ornamentation and the sensory canal pattern are distinct. They also differ in the presence of a median longitudinal groove in Ps. praecursor, and probably in the concavity of the anterior part of lateral margins in Ps. livonicus.

\section{CONCLUSION}

The new material of Middle and Upper Devonian psammosteids of the Baltic States is of interest from different points of view. Its main value lies in new data on the morphology of psammosteids. The probable complex plate found in Pycnosteus tuberculatus was unknown in psammosteids, except in Drepanaspis gemuendenensis. The new finds have been used in 
restorations published by Obruchev and Mark-Kurik (1968). One restoration, that of $P$. tuberculatus, is given in the present paper. Some of the finds are of interest from the point of view of individual variations and ontogenetic development. The recently discovered dorsal plate of Psammolepis toriensis has a great taxonomic value, for it allows to transfer this species from the genus Schizosteus to Psammolepis, thus establishing the early appearance of the latter genus.

\section{REFERENCES}

A ga s S i z L. 1844. Monographie des Poissons fossiles du vieux grès rouge ou système Dévonien (Old Red Sandstone) des Isles Britanniques et de Russie. Neuchâtel.

A gassiz L. 1845. Lettres sur les Poissons fossiles du système Dévonien de la Russie In: R. I. Murchison, E. de Verneuil et A. de Keyserling. Géologie de la Russie d'Europe et des Montagnes de l'Oural, t. 2. Paris.

Gros S W. 1963. Drepanaspis gemuendenensis Schlüter. Neuuntersuchung. Palaeontographica, Bd. 121, Abt. A.

Mark Е. (Марк Э. Ю.) 1955. Псаммостеиды (Agnatha) тартуского и гауйского горизонтов девона Әстонской ССР. Автореферат диссертации. Таллин.

Mark Е. (Марк Э. Ю.) 1956. О роде Pycnosteus (Psammosteidae, Agnatha). Tp. Ин-та геол. АН ЭССР, 1.

Obruchev D. (Обручев Д. В.) 1943. Yoglinia n. g., последний представитель птераспид из среднего девона Ленинградской области. Докл. АН СССР, т. 41, № 1.

Obruchev D. (Обручев Д. В.) 1947. О роде Psammosteus (Heterostraci). Докл. $\mathrm{AH}$ СССР, т. 56, № 5.

O bruchev D. (Обручев Д. В.) 1961. Род Tartuosteus (Psammosteidae) из среднего девона Прибалтики. Палеонт. журн., № 2.

Obruchev D. and Mark-Kurik E. (Обручев Д. В. и Марк-Курик Э. Ю.) 1965. Псаммостеиды (Agnatha, Psammosteidae) девона СССР. Таллин.

O bruchev D., Mark-KurikE. 1968. On the evolution of the psammosteids (Heterostraci). ENSV TA Toimet. Keem. Geol., nr. 3.

Preobrazhensky I. (Преображенский И. А.) 1911. О некоторых представителях сем. Psammosteidae Ag. Проток. О-ва естествоисп. Юрьевск. ун-та, т. 19, B. 3,4 .

Rohon J. V. 1901. Beiträge zur Anatomie und Histologie der Psammosteiden. Vĕstnik Ceské Spol. Nauk, r. 16.

T a r lo B. J. and Tarlo L. B. 1965. The origin of teeth. Discovery, Sept.

Tarlo L. B. 1961. Psammosteids from the Middle and Upper Devonian of Scotland. Quart. Journ. Geol. Soc. London, v. 117, No. 2.

T a r 10 L. B. 1965. Psammosteiformes (Agnatha) - A review with descriptions of new material from the Lower Devonian of Poland. II. Systematic part. Palaeont. Polonica, No. 15.

Traquair, R. H. 1896. The extinct vertebrate animals of the Moray Firth Area. In: J. A. Harvie-Brown \& T. E. Buckley. A vertebrate fauna of the Moray Basin, v. 2. Edinburgh.

Traquair R. H. 1897. Additional notes on the fossil fishes of the Upper Old Red Sandstone of the Moray Firth Area. Proc. Roy. Phys. Soc. Edinburgh, v. 13.

Academy of Sciences of the Estonian SSR, Institute of Geology 


\section{DEVONI PSAMMOSTEIIDIDE (HETEROSTRACI) UUED LEIUD EESTIST JA LATIST}

Artiklis kirjeldatakse mōningaid Baltikumi kesk- ja ülemdevoni psammosteiidide plaate. Osa neist on leitud esmakordselt, teisi tunti seni fragmentaarsete eksemplaride pōhjal. Leiud pakuvad huvi nimetatud rühma esindajate morfoloogia, süstemaatika, ontogeneesi ja individuaalse variatsiooni seisukohalt.

\section{Э. МАРК-КУРИК}

\section{НОВЫЕ НАХОДКИ ДЕВОНСКИХ ПСАММОСТЕИД (HETEROSTRACI) ИЗ ЭСТОНИИ И ЛАТВИИ}

Новые находки псаммостеид из среднего и верхнего девона Прибалтики дополняют материал, описанный в монографии Д. Обручева и Э. Марк-Курик (1965). Они использовались также при реконструкциях, опубликованных этими авторами в 1968 году. В статье дается детальное описание пластинок ряда псаммостеид, не известных до сих пор или мало известных: Tartuosteus maximus (Mark-Kurik), Pycnosteus tuberculatus (Rohon), Ganosteus stellatus Rohon, Psammolepis toriensis (MarkKurik), Psl. venyukovi Obruchev, Psammosteus bergi Obr., Ps. livonicus Obr. и Ps, praecursor Obr.

Дана новая реконструкция $P$. tuberculatus. На основании находки дорзальной пластинки, покрытой тессерами, Sch. toriensis отнесен к роду Psammolepis. Psl. toriensis является самым древним видом названного рода. Новый материал представляет интерес с точки зрения морфологии, систематики, онтогенетического развития и индивидуальной вариащии псаммостеид. 